Article

\title{
Formation Damage Avoidance by Reducing Invasion with Sodium Silicate-Modified Water-Based Drilling Fluid
}

\author{
Salaheldin Elkatatny * (D), Tural Jafarov, Abdulaziz Al-Majed and Mohamed Mahmoud \\ College of Petroleum Engineering and Geosciences, King Fahd University of Petroleum \& Minerals, \\ Dhahran 31261, Saudi Arabia; g201404080@kfupm.edu.sa (T.J.); aamajed@kfupm.edu.sa (A.A.-M.); \\ mmahmoud@kfupm.edu.sa (M.M.) \\ * Correspondence: elkatatny@kfupm.edu.sa; Tel.: +96-659-466-3692
}

Received: 2 April 2019; Accepted: 15 April 2019; Published: 19 April 2019

check for updates

\begin{abstract}
Drilling multilateral and horizontal wells through tight gas reservoirs is a very difficult task. The drilling fluid should be designed to reduce both fluid and solid invasion into the tight formation to avoid formation damage by aqueous phase trapping. The objective of this paper is to assess the effect of sodium silicate on the drilling fluid properties such as rheological and filtration properties. Rheological properties (RPs) were measured at different temperatures while the filtration test was performed at $300^{\circ} \mathrm{F}$ and 300 psi differential pressure. A retained permeability calculation was determined to confirm the prevention of solid invasion. The rheological properties results confirmed that the optimal concentration of sodium silicate (SS) was $0.075 \mathrm{wt} . \%$ and at the same time, the temperature has no effect on the SS optimum concentration. Using $0.075 \mathrm{wt} . \%$ of SS reduced the filtrate volume by $53 \%$ and decreased the filter cake thickness by $65 \%$. After mechanical removal of the filter cake, the return permeability of the tight sandstone core was $100 \%$ confirming the prevention of solid invasion. The computer tomography (CT) scanner showed that the CT number before and after the filtration test was very close (almost the same) indicating zero solid invasion and prevention of the formation damage.
\end{abstract}

Keywords: formation damage; solid invasion; water-based; drilling fluid; tight reservoirs; sodium silicate

\section{Introduction}

Water blockage (aqueous phase trapping) is a common issue while drilling unconventional and tight reservoirs. The viscosity of the gas is much lower than for water and as a result, a very high capillary pressure will be required to flow the gas and to remove the filtrate water, which filled the small pores of the tight formation.

Amanullah and Allen [1] illustrated that the drill-in fluid can cause several kinds of formation damage depending on the differential pressure, the bridging additives, spurt loss and the chemical composition of the fluid. The drill-in fluid should be formed to have a removable solid by the acid reaction, form an ideal filter cake and reduce or prevent the solid invasion, eliminate the reaction with the formation type, and compatible with the formation fluid [2]. Elkatatny et al. [3,4] showed that the filter cake is heterogeneous where the layer closed to the formation face contained the solids, which should be selected to form a bridging effect while drilling and it should be easy to remove after the drilling operation. Large-diameter bridging material should be used to plug the pore through the reservoir section of the South China Sea [5]. 


\subsection{Drilling Fluid Rheological Properties}

Rheological properties play a vital role in the optimization of drill-in fluids performance [6,7]. Rheological properties such as plastic viscosity (PV), yield point (YP) and gel strength are very important during the drilling operations [8]. The drilling mud density is responsible to control the formation pressure and at the same time increasing the fluid density will increase the solid percent and reduce the rate of penetration (ROP) [9]. Increasing the solid content in the drilling fluid will increase the PV and hence will reduce the ROP [10].

At annular velocity of less than $120 \mathrm{ft} / \mathrm{min}$, the PV and YP had a major effect on cutting transportation $[11,12]$. The carrying capacity index (CCI), which indicated the hole cleaning efficiency can be determined as a function of the consistency index [13]. It is very important to determine the yield stress of the drilling fluid, which represents the capability of the drilling fluid to carry the cutting to the surface [14].

Rig hydraulic calculations depend mainly on PV, YP, flow behavior index, and the flow consistency index. In addition to these parameters, the hole diameter and solid percent should be taken into consideration for the rig hydraulic calculations [15]. Taghipour et al. [16] concluded that non-circular holes showed better hole cleaning and lower pressure gradient as compared with circular holes.

Li et al. [17] concluded that for water-based drilling fluid, cellulose nanocrystals had the large effect of the rheological properties, where polyanionic cellulose has the big effect of filtration properties. Halali et al. [18] concluded that using nanoparticles can reduce the filtration by $95 \%$ at high-pressure high-temperature (HPHT) conditions and, in addition, nanoparticles can be used to overcome the issue of polymer degradation at HPHT conditions.

\subsection{Drill-in Fluids for Unconventional Reservoirs}

Tight gas reservoirs are the typical type of unconventional gas reservoirs with the permeability less than $0.1 \mathrm{mD}$ that produces mainly dry gas. Large hydraulic fracturing as a stimulation job must also be done in order to increase the recovery percentage from tight gas [19].

Water blockage is a common issue while drilling horizontal and multilateral wells through tight gas reservoirs which results from the invasion of filtrate fluid with very fine solids into the formation. To prevent water blockage, compatibility between formulated drill-in fluid and formation should be verified [20]. Liquid sodium silicate $\left(\mathrm{Na}_{2} \mathrm{SiO}_{3}\right)$ is strongly inhibitive material. Its particles in fresh water become in a gel state and form a film-like barrier throughout the rock [21].

Zabala et al. [22] introduced a stable drill-in fluid (7.4 ppg) for drilling heavy oil in Bare, Melones and Arecuna fields in Venezuela. They reported that this drill-in mud demonstrated no formation damage, in which the maximum filtrate volume became $5 \mathrm{ml}$ and return permeability was $89 \%$.

Van Zanten et al. [20] studied the effect of surfactant treatments after using water or brine-based drill-in fluids for altering wettability and elimination of emulsion blockage in tight oil and water blockage in tight gas formations. They concluded that the retained permeability was almost $100 \%$ when using microemulsion-forming surfactant packages.

El Bialy et al. [23] designed a drill-in fluid with potassium formate $(\mathrm{KCOOH})$ brine and manganese tetraoxide $\left(\mathrm{Mn}_{3} \mathrm{O}_{4}\right)$ weighting agent to provide $114 \mathrm{lb} / \mathrm{ft}^{3}$ density. It was used for drilling a vertical appraisal well to Unayzah A and B sandstone tight gas reservoirs in Saudi Arabia. The authors mentioned that since manganese tetraoxide is acid and enzyme soluble, they obtained very high (about $99.3 \%$ ) return permeability $(\mathrm{ki}=0.0606 \mathrm{mD}, \mathrm{kf}=0.0602 \mathrm{mD})$ with less than $14 \mathrm{ml}$ filtrate volume. It was also reported that the formulated drill-in fluid showed very high stability at the bottom hole temperatures exceeding $155^{\circ} \mathrm{C}$.

Han et al. [24] formulated sodium chloride $(\mathrm{NaCl})$ brine-based drill-in fluid with $3.5 \%$ potassium chloride $(\mathrm{KCl})$ and $3 \%$ glycol additives to drill four horizontal wells to Peregrino heavy oil field in Brazil. The oil density was 13 API. They determined that $3.5 \%$ potassium chloride $(\mathrm{KCl})$ and $3 \%$ glycol additives are ideal for the inhibition of moderately reactive shales. The retained permeability values 
for $\mathrm{NaCl} / \mathrm{KCl}$ WBM (Water-based mud) and LS OBM (Oil-based mud) between $68 \%$ and $76 \%$ with 6.8-7.2 and 1.9-2.9 $\mathrm{ml}$ fluid losses, respectively.

The main goal of this study is to formulate a proper non-damaging water-based drilling fluid with the optimum concentration of sodium silicate $\left(\mathrm{Na}_{2} \mathrm{SiO}_{3}\right)$ for tight gas reservoirs to minimize fluid invasion and prevent water blockage problem in the formation by forming a very thin, impermeable and easily removable filter cake. The ultimate goal was to increase the well productivity by gaining high return permeability. In addition to these objectives, the effect of SS on the rheological properties of the formulated drill-in fluid, barite solubility, and the sag performance will be assessed.

\section{Experimental Study}

\subsection{Water-Based Drilling Fluid}

The drilling fluid consists of distilled water as a base phase, $5 \mathrm{~g}$ of bentonite for viscosity control, xanthan gum ( $1 \mathrm{~g})$ for viscosity control, caustic soda $(0.25 \mathrm{~g})$ for $\mathrm{pH}$ control, sodium chloride $(22 \mathrm{~g})$ for shale stabilization and increase the density, starch (4 g) for filtration and viscosity control, calcium carbonate with different sizes ( $3 \mathrm{~g}$ of 25 microns and $3 \mathrm{~g}$ of less than 38 microns) works as weighting and bridging material, and barite $(278 \mathrm{~g})$ for density control. The mud was prepared and mixed at ambient conditions (e $\left(77^{\circ} \mathrm{F}\right.$ and $\left.14.7 \mathrm{psi}\right)$. Table 1 lists the composition of the drilling fluid.

Table 1. Drilling fluid formulation for lab scale.

\begin{tabular}{cc}
\hline Additives & Amount \\
\hline Distilled Water & $241.5 \mathrm{~cm}^{3}$ \\
Soda Ash $\left(\mathrm{Na}_{2} \mathrm{CO}_{3}\right)$ & $0.5 \mathrm{~g}$ \\
De-foamer & $0.01 \mathrm{~g}$ \\
Bentonite & $5 \mathrm{~g}$ \\
$\mathrm{XC}($ Xanthan gum) Polymer & $1 \mathrm{~g}$ \\
Caustic Soda $(\mathrm{NaOH})$ & $0.25 \mathrm{~g}$ \\
Sodium Chloride $(\mathrm{NaCl})$ & $22 \mathrm{~g}$ \\
Starch & $4 \mathrm{~g}$ \\
$\mathrm{CaCO}_{3}(25$ and $<38$ micron $)$ & $3+3 \mathrm{~g}$ \\
Barite & $278 \mathrm{~g}$ \\
\hline
\end{tabular}

The RPs were measured at room temperature $\left(77^{\circ} \mathrm{F}\right)$. Table 2 lists the RPs of the based fluid. The drilling fluid density was $14.5 \mathrm{ppg}$, the PV was $27 \mathrm{cP}$, the $\mathrm{YP}$ was $57 \mathrm{lb} / 100 \mathrm{ft}^{2}$, gel strength was 12 and $19 \mathrm{lb} / 100 \mathrm{ft}^{2}$ for $10 \mathrm{~s}$ and $10 \mathrm{~min}$, respectively, and $\mathrm{pH}$ was 10 . It is clear that the $\mathrm{YP} / \mathrm{PV}$ ratio was 2.11 at $77^{\circ} \mathrm{F}$.

Table 2. Drilling fluid rheological properties at room temperature.

\begin{tabular}{cc}
\hline Properties & Value \\
\hline Density, ppg & 14.5 \\
Plastic viscosity, $\mathrm{cP}$ & 27 \\
Yield point, lb/100 ft & 57 \\
10 sel strength, $\mathrm{lb} / 100 \mathrm{ft}^{2}$ & 12 \\
10 min gel strength, lb/100 ft ${ }^{2}$ & 19 \\
$\mathrm{pH}$ & 10 \\
\hline
\end{tabular}

\subsection{Experimental Procedure}

The following steps were conducted to assess the effect of using sodium silicate (SS) with a different percentage on water-based drilling fluid:

1. The drilling fluid was prepared and mixed using a different percentage of sodium silicate $(0,0.05$, 0.075 , and $0.1 \mathrm{wt} . \%)$. 
2. The fluid density and $\mathrm{pH}$ were measured at ambient conditions $\left(77^{\circ} \mathrm{F}\right.$ and $\left.14.7 \mathrm{psi}\right)$.

3. The rheological properties were measured at different temperature $\left(77,120,170\right.$, and $\left.300{ }^{\circ} \mathrm{F}\right)$.

4. The initial permeability of tight sandstone core ( 2 inch length and 2.5 inch thickness) was determined using the modified high-pressure-high temperature cell.

5. The filtration test was performed at $300^{\circ} \mathrm{F}$ and 300 psi differential pressure and the formed filter cake thickness was measured after using a different concentration of SS.

6. The formed filter cake was removed mechanically and the damage core permeability was obtained.

7. CT scan was performed for the core before the filtration and the mechanical removal of the filter cake.

8. The effect of sodium silicate on barite solubility was performed at $200^{\circ} \mathrm{F}$.

\section{Results and Discussion}

\subsection{Effect of Adding Sodium Silicate}

Different amounts of SS were added to the drilling fluid and the RPs were measured at $77^{\circ} \mathrm{F}$. The density and $\mathrm{pH}$ of water-based mud are measured at ambient condition $\left(77^{\circ} \mathrm{F}\right.$ and $\left.14.7 \mathrm{psi}\right)$ to simulate to real measurements of these properties in the field. It was noted that the drilling fluid density was $14.5 \mathrm{ppg}$ and it remained constant when increasing the amount of SS. The same result was obtained for $\mathrm{pH}$. The $\mathrm{pH}$ was 10 and it remained constant by increasing the SS concentration to $0.05,0.075$ and 0.1 wt. $\%$, Figure 1.

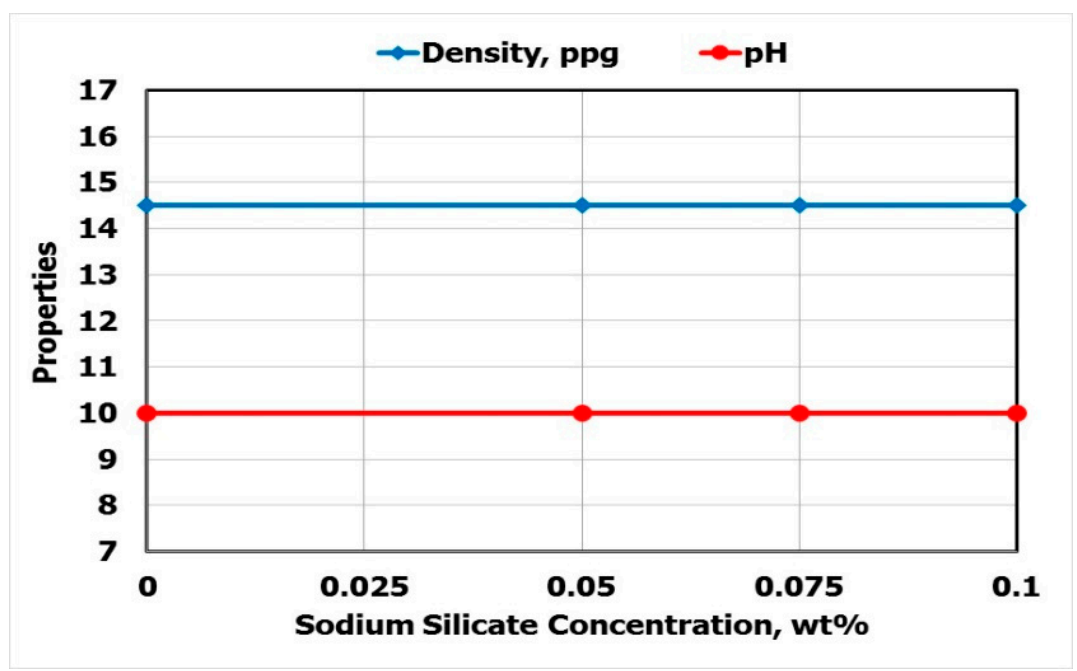

Figure 1. Effect of adding sodium silicate on drilling fluid density and $\mathrm{pH}$ at room temperature.

Figure 2a shows that the PV of the drilling fluid increased from $27 \mathrm{cP}$ to $32 \mathrm{cP}$ after adding $0.05 \mathrm{wt} . \%$ sodium silicate, and it increased to $35 \mathrm{cP}$ after adding $0.075 \mathrm{wt} . \%$ of sodium silicate. The $\mathrm{PV}$ decreased to $31 \mathrm{cP}$ after adding $0.1 \mathrm{wt} . \%$ of sodium silicate. These results confirmed that the optimal sodium silicate concentration was $0.075 \mathrm{wt} . \%$ at $77^{\circ} \mathrm{F}$. Drilling fluid's YP increased from 57 to $68 \mathrm{lb} / 100 \mathrm{ft}^{2}$ after adding $0.05 \mathrm{wt} . \%$ SS and increased to 75 after adding $0.075 \mathrm{wt} . \%$ of SS. The yield point decreased to 67 after adding $0.1 \mathrm{wt} . \%$ of SS. These results confirmed that the optimal concentration of SS is $0.075 \mathrm{wt} . \%$, Figure 2a.

Figure 2a shows that the optimal concentration of SS was $0.075 \mathrm{wt} . \%$ at which the $10 \mathrm{~s}$ and $10 \mathrm{~min}$ gel strength were 19 and $22 \mathrm{lb} / 100 \mathrm{ft}^{2}$, respectively. Based on the RPs, the optimal SS concentration was $0.075 \mathrm{wt} . \%$ at $77^{\circ} \mathrm{F}$. No effect was observed on the density and $\mathrm{pH}$ of the drilling fluid and no change in the YP/PV ratio. At the same time, the PV, YP, and gel strength were enhanced. 


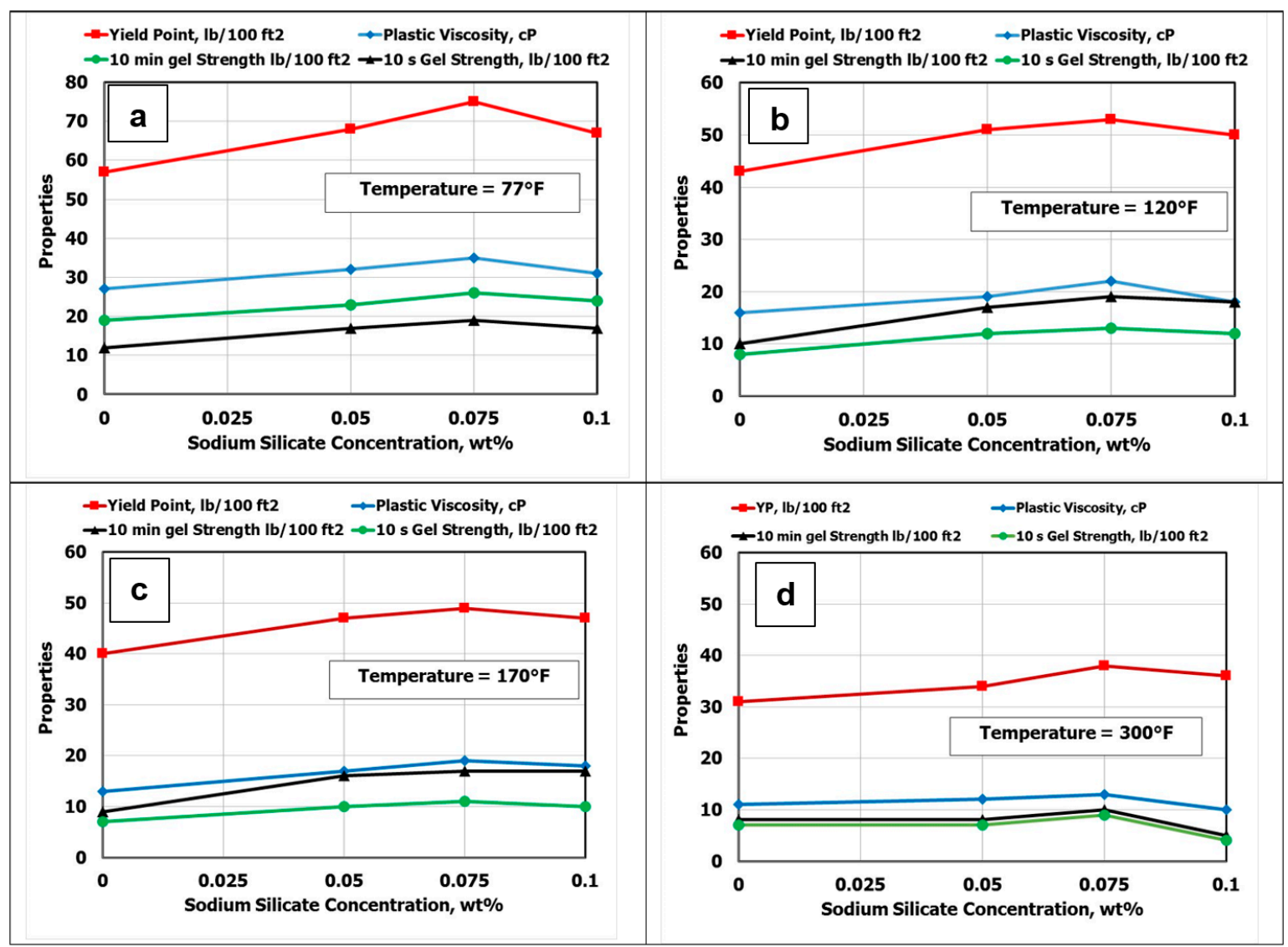

Figure 2. Effect of temperature on the rheological properties of water-based drilling fluid at a different concentration of SS. (a) At $77^{\circ} \mathrm{F}(\mathbf{b})$ at $120^{\circ} \mathrm{F}(\mathbf{c})$ at $170{ }^{\circ} \mathrm{F}(\mathbf{d})$ at $300^{\circ} \mathrm{F}$

\subsection{Effect of Temperature and Sodium Silicate (SS) Concentration}

To evaluate the effect of adding SS on the RPs of the drilling fluid at higher temperatures, the HPHT rheometer was used to measure the change in the RPs at 120,170 , and $300^{\circ} \mathrm{F}$.

Figure $2 \mathrm{~b}$ shows that adding SS with different concentrations ( 0.05 to $0.1 \mathrm{wt} . \%)$ enhanced the RPs of the drilling fluid, as discussed by Guo et al. [21]. The optimal concentration of SS at $120^{\circ} \mathrm{F}$ was $0.075 \mathrm{wt} . \%$ at which the PV was $22 \mathrm{cP}$ and the YP was $53 \mathrm{lb} / 100 \mathrm{ft}^{2}$, the $10 \mathrm{~s}$, and $10 \mathrm{~min}$ gel strength were 13 and $19 \mathrm{lb} / 100 \mathrm{ft}^{2}$, respectively. It was clear that the $\mathrm{YP} / \mathrm{PV}$ ratio was 2.5 at $120^{\circ} \mathrm{F}$, which confirmed the good RPs of the drilling fluid when using $0.075 \mathrm{wt} . \% \mathrm{SS}$. This ratio is responsible for carrying the drilled cuttings of the rock from the drilled hole to the surface and it is recommended to be greater than 1.5 .

The same behavior was observed at $170{ }^{\circ} \mathrm{F}$ as shown in Figure 2c. The optimal concentration was $0.075 \mathrm{wt} . \%$ of SS at which the PV was $19 \mathrm{cP}$ and the YP was $49 \mathrm{lb} / 100 \mathrm{ft}^{2}$, the $10 \mathrm{~s}$, and $10 \mathrm{~min}$ gel strength was 11 and $17 \mathrm{lb} / 100 \mathrm{ft}^{2}$, respectively. At $300^{\circ} \mathrm{F}$, the optimal concentration of SS was $0.075 \mathrm{wt} . \%$ at which the PV was $13 \mathrm{cP}$ and the $\mathrm{YP}$ was $38 \mathrm{lb} / 100 \mathrm{ft}^{2}$ resulting in a YP/PV ratio of 2.9 which is very good for hole cleaning. The gel strength was 9 and $10 \mathrm{lb} / 100 \mathrm{ft}^{2}$ for $10 \mathrm{~s}$ and $10 \mathrm{~min}$, respectively, Figure 2d. Guo et al. [21] stated that SS particles in fresh water assume a gel state, which will increase the gel strength of the fluid.

Figure 3 shows the change of the shear stress-shear rate behavior at a different temperature for the drilling fluid with SS concentration of $0.075 \mathrm{wt} . \%$. It is clear the stress behavior of the drilling fluid decreased by increasing the temperature. The shear stress reduced from $144.1 \mathrm{lb} / 100 \mathrm{ft}^{2}$ to $64 \mathrm{lb} / 100 \mathrm{ft}^{2}$ at a shear rate of 600 when using the optimal concentration of SS (0.075 wt.\%). Based on these results, it can be concluded that adding SS with $0.075 \mathrm{wt} . \%$ enhanced the RPs of the drilling fluid over a wide 
range of temperature $\left(77\right.$ and $\left.300^{\circ} \mathrm{F}\right)$. In other word, the temperature had no effect on the optimal concentration value of SS.

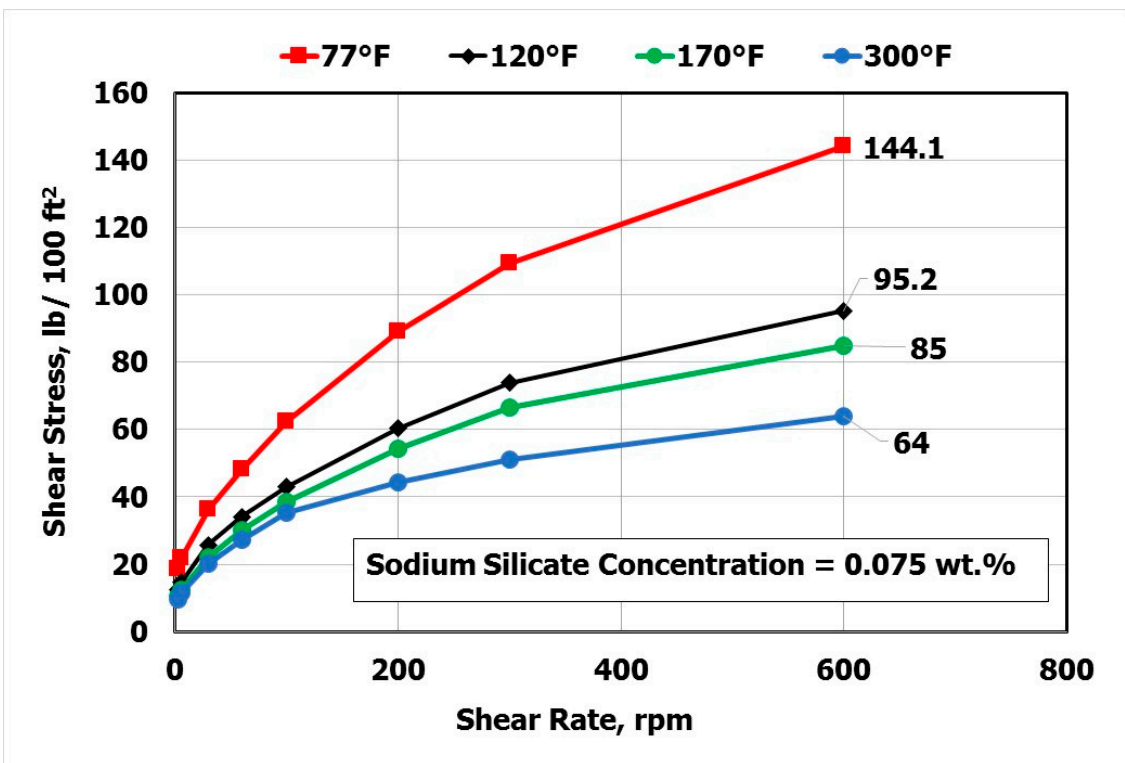

Figure 3. Effect of temperature on the shear stress-shear rate behavior of the drilling fluid with 0.075 wt. $\%$ SS.

\subsection{Effect of Sodium Silicate on Barite Solubility}

To evaluate the effect of adding SS on barite solubility, a hot plate magnetic stirrer was used at $200{ }^{\circ} \mathrm{F}$, Figure 4 . The solubility test was performed using $4 \mathrm{gm}$ of barite in $100 \mathrm{ml}$ solution which contains $20 \mathrm{wt} . \%$ EDTA (Ethylenediaminetetraacetic acid) at $\mathrm{pH} 12$, and $6 \mathrm{wt} . \%$ potassium carbonate, this solution was proposed by Bageri et al. [25] for barite filter cake removal. Figure 5 shows that the solubility of barite was $75 \mathrm{wt} . \%$ before adding SS. The barite solubility increased from 75 to $80 \%$ by adding 2 wt. $\%$ of SS and it further increased to $82 \%$ when 4 wt.\% SS was used. The barite solubility decreased to $80 \%$ when 6 wt.\% of SS was used, Figure 5. Based on these experiments, it can be concluded that adding SS enhanced barite solubility and sodium silicate worked as a catalyst that enhanced the barite solubility. The enhancement in the solubility of sodium silicate due to the addition of sodium silicate can be attributed to the fact that sodium silicate acted as a sequestering agent for multivalent cations (such as barium, calcium, etc.) [26].

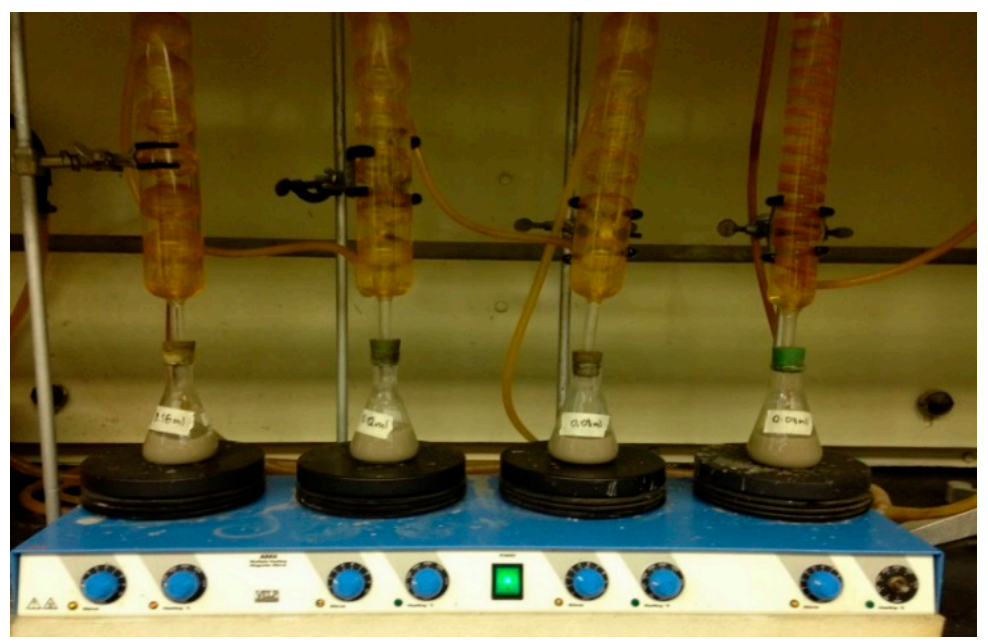

Figure 4. Hot plate magnetic stirrer for solubility evaluation. 


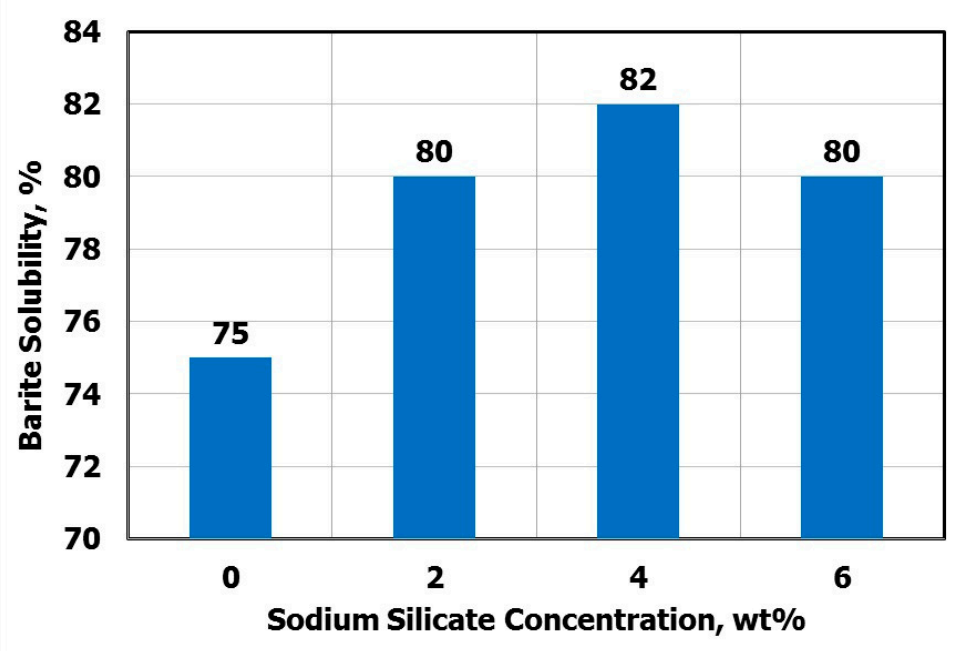

Figure 5. Effect of adding sodium silicate on barite solubility at $200^{\circ} \mathrm{F}$.

\subsection{Effect of Sodium Silicate on Filtration}

The filtration test was conducted at $300^{\circ} \mathrm{F}$ and 300 differential pressure. To simulate the reservoir rock, tight sandstone core ( $0.25^{\prime \prime}$ thickness and $2.5^{\prime \prime}$ diameter) was used. Another set of cores with 2 inch length and 2.5 inch diameter were used to perform the filtration test using the modified HPHT cell. The cores were cut and prepared from a Scioto sandstone block which had an average permeability of $1.3 \mathrm{mD}$ and average porosity of $12 \%$.

Figure 6 shows that the cumulative filtrate volume was $7.4 \mathrm{~cm}^{3}$ after 30 minutes of filtration. This experiment was conducted using zero percent of SS. The cumulative volume filtration decreased from 7.4 to $6.5 \mathrm{~cm}^{3}$ when $0.05 \mathrm{wt}$.\% of SS was used, Figure 6 . By increasing the concentration of SS to $0.075 \mathrm{wt} . \%$, the cumulative filtrate volume decreased to $3.5 \mathrm{~cm}^{3}$, while it further increased to $5 \mathrm{~cm}^{3}$ after increasing the concentration of SS to $0.1 \mathrm{wt} . \%$. These results indicated that using $0.075 \mathrm{wt} . \%$ of SS, the cumulative filtrate volume decreased by $53 \%$. Based on filtration results, $0.075 \mathrm{wt} . \% \mathrm{SS}$ is the optimal concentration that should be used in the drilling fluid. Young and Friedheim [27] obtained very close results to the aforementioned results when using $3 \mathrm{wt}$.\% nano-sized silica solution for Mancos shale and Texas shale gas core samples. The total filtrate volume was $8.8 \mathrm{~cm}^{3}$ at a temperature of $200^{\circ} \mathrm{F}$ and 500 psi applied pressure.

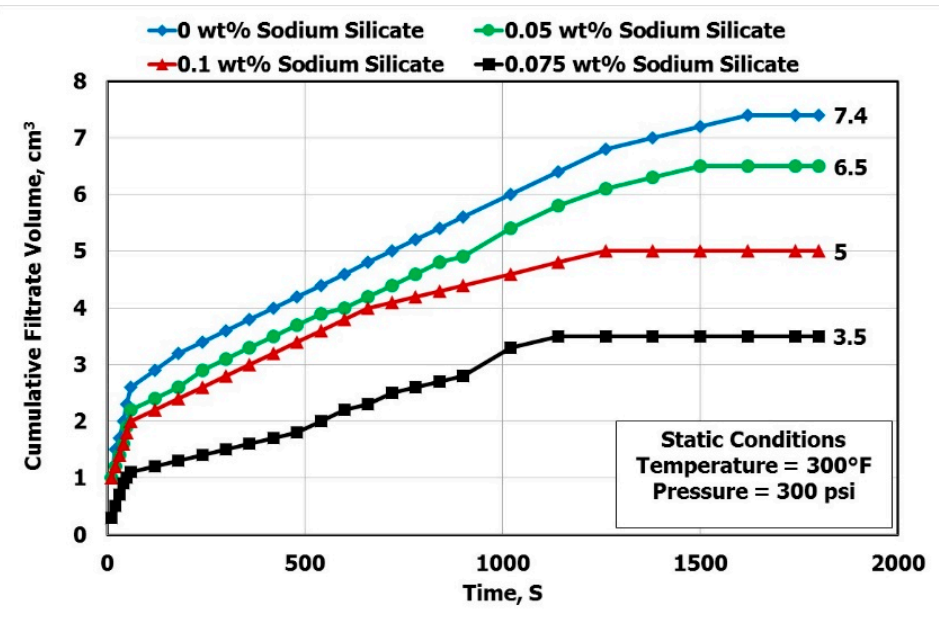

Figure 6. Effect of adding sodium silicate on filtrate volume. 
The filter cake thickness was measured after every filtration test, the filter cake thickness was $2 \mathrm{~mm}$ when no SS was used, Figure 7. By increasing the concentration of SS to $0.05 \mathrm{wt} . \%$, the filter cake thickness decreased from 2 to $1.8 \mathrm{~mm}$., the cake thickness further decreased from 1.8 to $0.7 \mathrm{~mm}$ when $0.075 \mathrm{wt} . \%$ SS was used, while the cake thickness increased to $1.3 \mathrm{~mm}$ after increasing the concentration of SS to $0.1 \mathrm{wt} . \%$, Figure 7 . The filter cake thickness decreased by $65 \%$ by adding $0.075 \mathrm{wt} . \%$ of SS. These results confirmed that the optimal concentration of SS was $0.075 \mathrm{wt} . \%$.

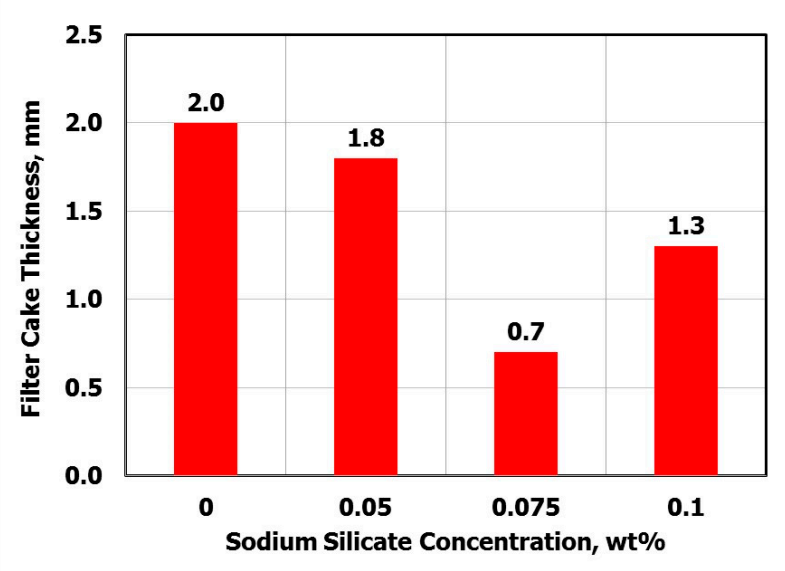

Figure 7. Effect of adding sodium silicate on filter cake thickness.

\subsection{Retained Permeability}

To assess the damaging effect of the developed formulation of the drilling fluid which contained $0.075 \mathrm{wt} . \%$ of SS on tight sandstone cores, the filter cake formed on the face of the core was removed mechanically and the final permeability of the core was calculated. Figure 8 shows the core before the filtration and a CT scan cross-section of the core before the damage. In addition, Figure 8 shows the formed filter cake with a CT scan for the core after damage with the cake on its surface.

The initial and final permeability of the Scioto sandstone core was measured using Darcy's law. The experiment was repeated four times and the average permeability was calculated. The retained permeability was determined as explained by Elkatatny and Nasr-El-Din [28].

For Scioto sandstone cores, the retained permeability was $100 \%$. The experiment was repeated four times and the same results were obtained. This result confirmed that there was no solid invasion inside the core. To confirm the retained permeability results, computer tomography (CT) was used to scan one core before the filtration test and after the mechanical removal of the filter cake.

Figure 9 shows the slices of the CT scan through the core before the filtration and after damaging the core using the drilling fluid formed with $0.075 \mathrm{wt}$.\% SS. The color of the slices in Figure $9 \mathrm{a}, \mathrm{b}$ are very close throughout the core length which confirmed that there is no solid invasion after the filtration test. For further analysis, the average CT number was determined before the filtration process and after the mechanical removal of the filter cake. Figure 10 shows that the average CT number was the same through the core length before and after the filtration, confirming that there was no solid invasion.

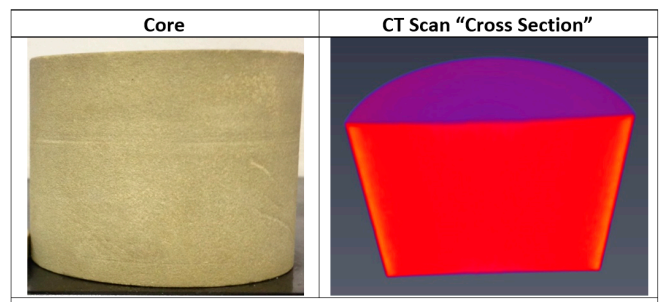

(a) Before Damage

Figure 8. Cont. 


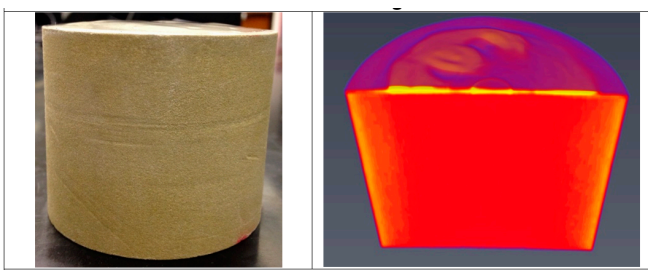

(b) After Damage

Figure 8. Photos of the original core and computer tomography (CT) images before damage (a) and after damage (b).

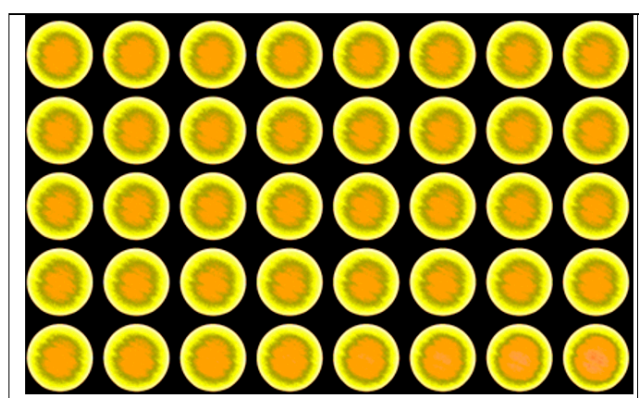

(a)

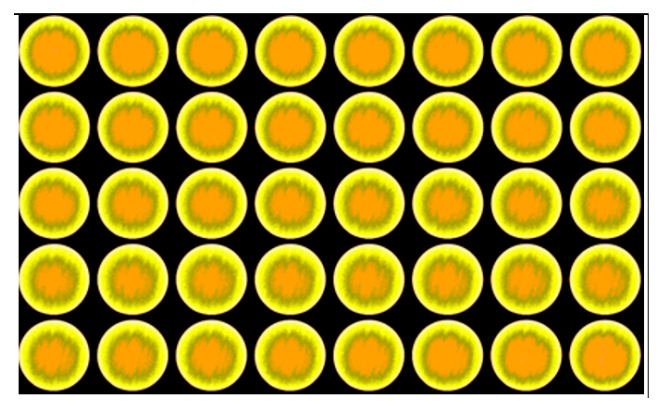

(b)

Figure 9. CT scan slices through the core (2" thickness and 2.5" diameter) where (a) shows the core before filtration and $(\mathbf{b})$ shows the core after the filtration.

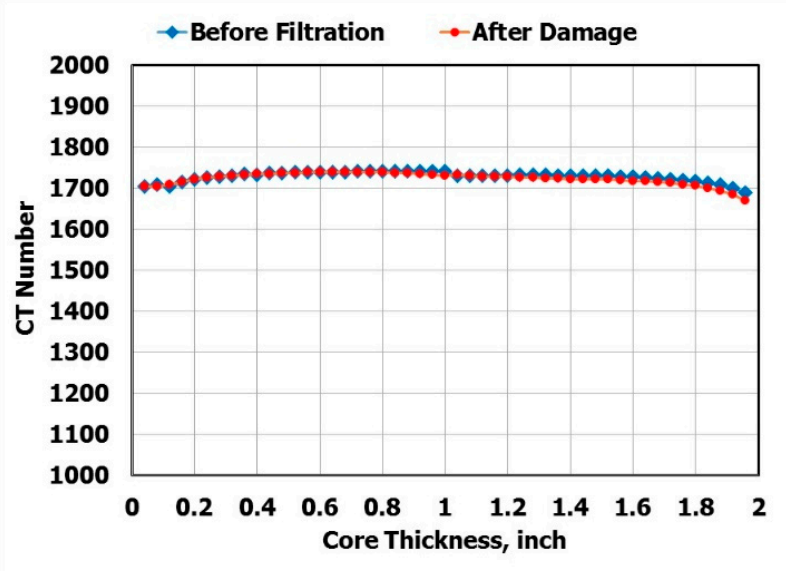

Figure 10. Computer tomography scan before filtration and after damaging the tight sunstone core with the drilling fluid.

\subsection{Mechanism of Sodium Silicate in Barite Water-Based Drilling Fluids}

To understand the mechanism of $0.075 \mathrm{wt} . \% \mathrm{Na}_{2} \mathrm{SiO}_{3}$ in barite water-based drilling fluid, it will be explained using two different approaches. The two approaches were developed for barite recovery, however, these methods can be implemented in petroleum engineering as well. Since barite is the only non-soluble solid in the drilling fluid and the different concentrations of $\mathrm{Na}_{2} \mathrm{SiO}_{3}$ are the additive that shows improvement through all the experiments, both approaches were considered together to explain our case as well. These approaches are barite flotation recovery with respect to $\mathrm{Na}_{2} \mathrm{SiO}_{3}$ concentrations, and the solubility of sodium silicate with the $\mathrm{pH}$ value of the solution.

Barite flotation recovery is the process in which sodium silicate is used as a reagent to suspend and extract barite, and there is a strong relation between barite recovery and the amount of sodium silicate used. Bulatovic [29] showed that the maximum barite recovery was obtained at $0.2 \mathrm{wt} . \%$ ratio 
of sodium silicate to barite. The optimal concentration of the sodium silicate in the drilling fluid is $0.075 \mathrm{wt} . \%$, according to the results obtained by Bulatovic [29], and this concentration of sodium silicate will suspend $91 \%$ of the barite in the drilling fluid. The remaining $9 \%$ of barite will settle and form a very thin filter cake on the formation face (which is favorable in drilling operations). The thin, impermeable filter cake is needed to prevent the solids and fluid invasion to the oil and gas reservoir rock because this invasion will diminish oil and gas production. Also, the relation between the sodium silicate concentration and barite recovery indicates why the filter cake thickness increased when the sodium silicate concentration decreased to $0.05 \mathrm{wt} . \%$. At $0.05 \mathrm{wt} . \%$ sodium silicate concentration, the amount of suspended barite will be $86 \%$ and the remaining $14 \%$ will precipitate to form the filter cake compared to $9 \%$ at $0.075 \mathrm{wt}$.\% sodium silicate concentration. Figures 7 and 11 show the relation between sodium silicate concentration and the filter cake thickness due to barite settling for concentrations up to $0.075 \mathrm{wt} . \%$.

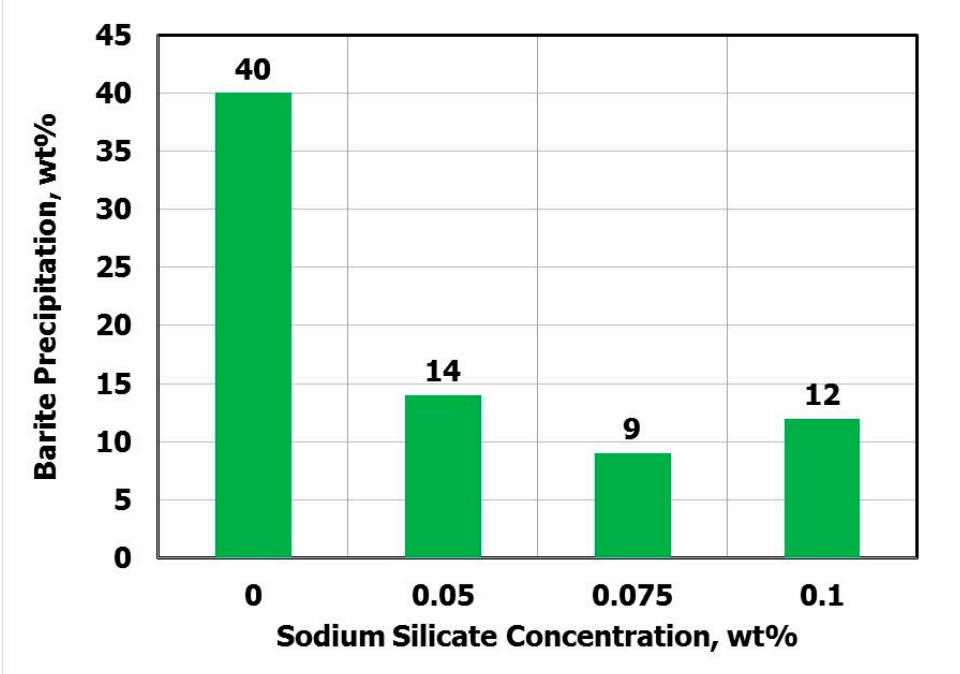

Figure 11. Effect of sodium silicate concentration on barite precipitation.

The general formula of sodium silicate is $\mathrm{Na}_{2} \mathrm{O} \cdot \mathrm{SiO}_{2}$. It has two parts: $\mathrm{Na}_{2} \mathrm{O}$ and $\mathrm{SiO}_{2}$. When $\mathrm{Na}_{2} \mathrm{SiO}_{3}$ is added to the drilling fluid solution, $\mathrm{Na}_{2} \mathrm{O}$ will react with water to generate sodium hydroxide. This reaction will reduce the amount of sodium oxides and the silicon oxide will remain in the solution. Ives [30] showed that the sodium silicate solubility depends on its concentration and the solution $\mathrm{pH}$. In the drilling fluid, the $\mathrm{pH}$ is 10 ; at this $\mathrm{pH}$, sodium silicate will be in the amorphous form if the concentration exceeds $0.015 \mathrm{~mol} / \mathrm{L}(0.075 \mathrm{wt} . \%)$ and below this concentration, sodium silicate will be in the polymerization region. This is why when the concentration increased beyond $0.075 \mathrm{wt} . \%$, the filter cake thickness increased and the sodium silicate amorphous form was generated and did not prevent the barite settling. In the polymerization process that happens at concentrations lower than $0.075 \mathrm{wt} . \%$, siloxane $\left(\mathrm{Si}_{4} \mathrm{O}_{8}(\mathrm{OH})_{44^{-}}\right)$will form. The interaction between barite and polymerized $\mathrm{Si}_{4} \mathrm{O}_{8}(\mathrm{OH})_{44^{-}}$will result in the suspension of barite particles. The last part of the polymerization process is gelation. At this stage, when the polymer is exposed to the $\Delta \mathrm{P}$, it is flushed out of a solution and plugs the formation face by making a film-like barrier. As a result, the fluid invasion is minimized and solid invasion completely stops because of the polymerization effect of $0.075 \mathrm{wt} . \% \mathrm{Na}_{2} \mathrm{SiO}_{3}$.

\section{Conclusions}

Extensive laboratory experiments were conducted to evaluate the effect of using sodium silicate on water-based drilling fluid properties. The following conclusions can be drawn based on the results obtained: 
1. Sodium silicate had no effect of fluid density and $\mathrm{pH}$. In addition, there was no change in the yield point plastic viscosity ratio.

2. The optimal SS concentration was $0.075 \mathrm{wt} . \%$ and the temperature had no effect on this value over a wide range $\left(77-300^{\circ} \mathrm{F}\right)$.

3. Using $0.075 \mathrm{wt} . \%$ of SS the filtrate volume was reduced by $53 \%$ and the filter cake thickness was decreased by $65 \%$.

4. The CT scan and the return permeability calculation after the mechanical removal of the filter cake confirmed that there was no solid invasion after the filtration test at $300^{\circ} \mathrm{F}$ and applied differential pressure of 300 psi.

Author Contributions: Conceptualization, S.E. and M.M.; methodology, A.A.-M.; experimental, T.J.; validation, S.E., M.M.; formal analysis, S.E.; investigation, A.A.-M.; resources, M.M.; data curation, A.A.-M.; writing-original draft preparation, S.E. and T.J.; writing—review and editing, T.J., M.M.; visualization, A.A.-M.; supervision, A.A.-M.

Funding: This research received no external funding.

Conflicts of Interest: The author declares no conflict of interest.

\section{References}

1. Amanullah, M.; Allen, T. Extended Aramco Method-Its Technico-Economic Significance in Non-Damaging Drill-in Fluid Design. Presented at the SPE/IADC Middle East Drilling Technology Conference and Exhibition, Dubai, UAE, 7-9 October 2013.

2. Mandal, N.G.; Jain, U.K.; Anil Kumar, B.S.; Gupta, A.K. Nondamaging Drilling Fluid Enhances Borehole Quality and Productivity in Conventional Wells of Mehsana Asset, North Cambay Basin. Presented at the SPE/IADC Indian Drilling Technology Conference and Exhibition, Mumbai, India, 16-18 October 2016.

3. Elkatatny, S.M.; Mahmoud, M.A.; Nasr-El-Din, H.A. Characterization of Filter Cake Generated by Water-Based Drilling Fluids Using Ct Scan. SPE Drill. Complet. 2012, 27, 282-293. [CrossRef]

4. Elkatatny, S.M.; Mahmoud, M.; Nasr-El-Din, H. Filter Cake Properties of Water-Based Drilling Fluids under Static and Dynamic Conditions Using CT Scan. J. Energy Resour. Technol. 2013, 135. [CrossRef]

5. Zhao, X.; Qiu, Z.; Sun, B.; Liu, S.; Xing, X.; Wang, M. Formation damage mechanisms associated with drilling and completion fluids for deep water reservoirs. J. Pet. Sci. Eng. 2019, 173, 112-121. [CrossRef]

6. Fakoya, M.F.; Ahmed, R.M. A generalized model for apparent viscosity of oil-based muds. J. Pet. Sci. Eng. 2018, 165, 777-785. [CrossRef]

7. Elkatatny, S.M.; Zeeshan, T.; Mahmoud, M.A. Real Time Prediction of Drilling Fluid Rheological Properties Using Artificial Neural Networks Visible Mathematical Model (White Box). J. Pet. Sci. Eng. 2016, 146, 1202-1210. [CrossRef]

8. Power, D.; Zamora, M. Drilling Fluid Yield Stress: Measurement Techniques for Improved Understanding of Critical Drilling Fluid Parameters. In Proceedings of the AADE-03 NTCE-35, AADE Technical Conference, Houston, TX, USA, 1-3 April 2003.

9. Mitchell, R.F.; Miska, S.Z. Fundamentals of Drilling Engineering; Society of Petroleum Engineers: London, UK, 2011.

10. Estes, J.C. Guidelines for Selecting Rotary Insert Rock Bits. Pet. Eng. 1974, 9, 30-34.

11. Hussaini, S.M.; Azar, J.J. Experimental Study of Drilled Cutting Transport Using Common Drilling Muds. SPE J. 1983, 23, 11-20. [CrossRef]

12. Rao, M.A. Rheology of Fluid and Semisolid Foods, 2nd ed.; Springer Science + Business Media LLC: New York, NY, USA, 2007.

13. Robinson, L.; Morgan, M. Effect of hole cleaning on drilling rate performance. Presented at the AADE Drilling Fluid Conference, Houston, TX, USA, 6-7 April 2004.

14. Nasiri, M.; Ashrafizadeh, S.N. Novel Equation for the Prediction of Rheological Parameters of Drilling Fluids in an Annulus. Ind. Eng. Chem. Res. 2010, 49, 3374-3385. [CrossRef]

15. Zhang, F.; Miska, S.; Yu, M.; Ozbayoglu, E.M.; Takach, N. Pressure Profile in Annulus: Solids Play a Significant Role. J. Energy Resour. Technol. 2015, 137, 064502. [CrossRef] 
16. Taghipour, A.; Lund, B.; Ytrehus, J.D.; Skalle, P.; Saasen, A.; Reyes, A.; Abdollahi, J. Experimental Study of Hydraulics and Cuttings Transport in Circular and Noncircular Wellbores. J. Energy Resour. Technol. 2014, 136, 022904.

17. Li, M.; Wu, Q.; Song, K.; De Hoop, C.; Lee, S.; Qing, Y.; Wu, Y. Cellulose Nanocrystals and Polyanionic Cellulose as Additives in Bentonite Water-Based Drilling Fluids: Rheological Modeling and Filtration Mechanisms. Ind. Eng. Chem. Res. 2016, 55, 133-143. [CrossRef]

18. Halali, M.A.; Ghotbi, C.; Tahmasbi, K.; Ghazanfari, M.H. The Role of Carbon Nanotubes in Improving Thermal Stability of Polymeric Fluids: Experimental and Modeling. Ind. Eng. Chem. Res. 2016, 55, 7514-7534. [CrossRef]

19. Lake, L.W.; Fanchi, J.R.; Mitchell, R.F.; Arnold, K.E.; Clegg, J.D.; Holstein, E.D.; Warner, H.R., Jr. Petroleum Engineering Handbook; Society of Petroleum Engineers: Houston, TX, USA, 2007; Volume 6.

20. Van Zanten, R.; Horton, D.; Tanche-Larsen, P. Engineering Drill-in Fluids to Improve Reservoir Producibility. Presented at the SPE European Formation Damage Conference, Noordwijk, The Netherlands, 7-10 June 2011.

21. Guo, J.; Yan, J.; Fan, W.; Zhang, H. Applications of strongly inhibitive silicate-based drilling fluids in troublesome shale formations in Sudan. J. Pet. Sci. Eng. 2006, 50, 195-203. [CrossRef]

22. Zabala, E.; Luongo, A.; Parra, E.; Mendez, J.; Arocha, J.; Carrasquero, J. Field Experiences with Stable Mul, a Non Damaging Micro Emulsion Used as Drilling Fluid for Heavy Oil Formations in Venezuela. Presented at the SPE International Thermal Operations and Heavy Oil Symposium, Bakersfield, CA, USA, 17-19 March 1999.

23. El Bialy, M.; Mohsen, M.; Ezell, R.G.; Abdulaziz, M.E.; Kompantsev, A.; Khakimov, A.; Ganizade, F.; Ashoor, A. Utilization of Non-Damaging Drilling Fluid Composed of Potassium Formate Brine and Manganese Tetra Oxide to Drill Sandstone Formation in Tight Gas Reservoir. Presented at the SPE/IADC Middle East Drilling Technology Conference and Exhibition, Muscat, Oman, 24-26 October 2011.

24. Han, L.; Clinch, D.; van der Zwaag, C.; Galletti, E.; Fornasier, F.; Estevez, F.; McMillan, N.; Green, J.; Patey, I. Customizing Drill-in Fluid for Peregrino Project in Brazil: Laboratory Development and Field Experience. Presented at the SPE International Symposium and Exhibition on Formation Damage Control, Lafayette, LA, USA, 15-17 February 2012.

25. Bageri, B.; Mahmoud, M.A.; Abdulraheem, A.; Al-Mutairi, S.H.; Elkatatny, S.M.; Shawabkeh, R.A. Single Stage Filter Cake Removal of Barite Weighted Water Based Drilling Fluid. J. Pet. Sci. Eng. 2017, 149, 476-484. [CrossRef]

26. Volpe, D. Assessment of Iron and Manganese Sequestration. Master's Thesis, University of Massachusetts Amherst, Amherst, MA, USA, 2012.

27. Young, S.; Friedheim, J. Environmentally Friendly Drilling Fluids for Unconventional Shale. Presented at the 11th Offshore Mediterranean Conference and Exhibition, Ravenna, Italy, 20-22 March 2013.

28. Elkatatny, S.M.; Nasr-El-Din, H. Removal of Water-Based Filter Cake and Stimulation of the Formation in One-Step Using an Environmentally Friendly Chelating Agent. Int. J. Oil Gas Coal Technol. 2014, 7, 169-188. [CrossRef]

29. Bulatovic, S.M. Handbook of Flotation Reagents: Chemistry, Theory and Practice_Flotation of Industrial Minerals; Elsevier: Amsterdam, The Netherlands, 2007; Volume 3.

30. Ives, K.J. The Scientific Basis of Flotation; Martinus Nijhoff Publishers: Hague, The Netherlands, 2012.

(C) 2019 by the authors. Licensee MDPI, Basel, Switzerland. This article is an open access article distributed under the terms and conditions of the Creative Commons Attribution (CC BY) license (http://creativecommons.org/licenses/by/4.0/). 